\title{
Analysis of Competition Reviewed From Consumer Attitudes to Yellow Tofu Attributes in Kediri City
}

\author{
Kartika Yuliari ${ }^{1,}$ Dhian Rosalina ${ }^{2}$, Muhammad Dian Ruhamak ${ }^{3}$ \\ ${ }^{1}$ Departement of Economics, Kadiri University, East Java, Indonesia ${ }^{2}$ Departement of Economics, Samudra University, \\ Medan, Indonesia ${ }^{3}$ Departement of Economics, Kadiri University, East Java, Indonesia
}

*Corresponding author. kartikay@unik-kediri.ac.id

\begin{abstract}
In assessing the competitiveness of a product, consumer perceptions play an important role in knowing several potential and superiority of the product. The purpose of this study was to determine the attitudes of consumers towards several attributes in the typical yellow Tofu Kediri City. Respondents in this study were yellow tofu buyers at the culinary center of Kediri, namely on Pattimura Street and Yos Sudarso Street. The approach usedin data analysis uses the Fishbein multi-attribute model. From the results of the study found that five attributes are considered very important for consumers in purchasing yellow Tofu, namely: taste, nutrition, product safety, texture, and packaging. While in terms of competitiveness, Tahu Kuning Kota Kediri is in the attribute of feeling, which has the highest score, while the price attribute is an attribute that has the lowest score in the competitiveness of the product
\end{abstract}

Keywords: Consumer Attitude, Competitiveness, Yellow Tofu Attributes.

\section{INTRODUCTION}

Micro, Small, and Medium Enterprises are smallscale businesses that can contribute to the economy. They can survive crises ([1] so that Small and Medium Enterprises have an essential role in the national economy [2] because the existence of small businesses can open jobs and absorb unemployment rates nationally. The number of Small and Medium Enterprises engaged in the food sector is quite a lot in Indonesia. It contributes to the most extensive production value [2], one of the food sectors is processed soybeans in the form of Tofu. Tofu is one of the foods that are generally known by the people of Indonesia and consumed daily. [3] this is because Tofu has a good taste for the community at alow price and has a high protein content. Two types of Tofu are widely known by the public, namely white Tofu, and yellow
Tofu. Yellow Tofu is Tofu with distinctive yellow color, and rectangular shape, which is slightly dense textured, is a product by which it is characteristic of the City of Kediri, Indonesia. Based on data collected in a study conducted by Parestyna, 2013, that in the records of the Department of Industry and Trade of the City of Kediri 27 Tofu Industries had formal business licenses and 138 non- formal tofu industries that did not have business licenses, where generally producers tofu produces two types of Tofu namely white and yellow Tofu. So by seeing the large number of tofu entrepreneurs, the City of Kediri is called the City of Tofu.

Consumer attitude is one of the critical factors in influencing consumers when purchasing a product [2] ). Perspectives describe the level of consumer confidence in all attributes and the benefits that accompany the product [5]. By examining consumer attitudes, small businesses can find out how consumers trust a product 
and evaluate the product when it is a purchase. Seeing that the current market conditions for yellow tofu products are potential, the behavior of the public in buying quality yellow tofu needs to be studied further, so that the presence of the Kediri tofu industry players can still exist and be evenly able to produce healthy yellow tofu products that are in accordance with consumer expectations in general.

\subsection{Formulation of the Problem}

The formulation of the problem in this study are as follows:

a. What is the attitude of consumers towards the Yellow Tofu attribute?

b. How does the competitiveness of the tofu attribute from the consumer's attitude?

Engel JF, Blackwell reveals one model of consumer behavior states that there are factors that have a simultaneous influence on consumer decisions when choosing and buyingproducts.

These factors are:

a. Environmental influences, namely consumer social environments such as; social hierarchy/class, personal authority, family norms.

b. Individual differences, namely differences between individuals inherent in each consumer such as stereotype, motivation, attitude

c. Psychological Process is a process that occurs in consumers before buying or choosing which consists of information processing, learning, changing attitudes/behavior.

Attitudes are evaluations, emotions, and actions both tend to be beneficial or not, and consistently persist in individuals against particular objects [6] Attitude is a form of individual expression in reflecting likes and dislikes of an object. Consumer attitude is a form of expression of consumer feelings regarding the belief that a product has a series of attributes and benefits of these attributes [7]. Thus, anattitude has a central role in predicting potential purchases [5].

From various studies on consumer behavior summarized byPurwidiantoro, S.W, \& Hadi, (2016). An attitude is a form of a comprehensive evaluation carried out by consumers. Itmakes it possible for consumers to respond beneficially or not to the object being assessed. Then some research also shows that consumers involved in the purchasing Process are willing to pay more because of specific attributes that are considered quality [9]. In determining the choice of products, consumers have several characteristics that are evaluated on the product; this model is often called the Multi-Attitude Attitude Model. From research conducted by Lestari (2017), Multi-product attributes generally use product quality criteria such as 1 . Product price, 2 . Producttaste, 3. Product size, 4. Product color, 5. Freshness condition, 6. Product aroma, 7. Product texture, and 8. Nutrition.

Whereas in this study, the indicators of consumer attitudes in selecting the desired attributes of the desired yellow tofuproduct consist of seven criteria, namely: 1 . Taste, 2. Nutrition, 3. Product Safety, 4. Texture, 5. Price, 6. Packaging, 7. Smell of Tofu

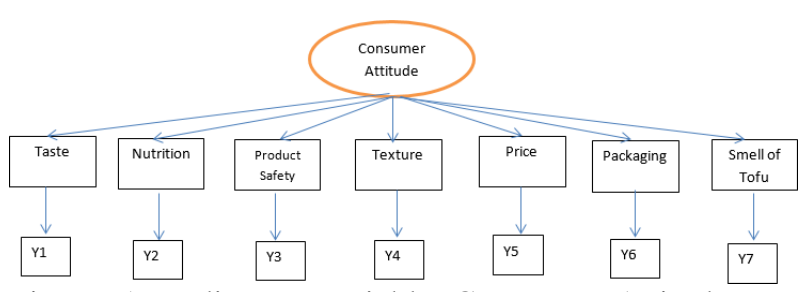

Figure 1. Indicator Variable Consumer Attitudes Toward Yellow Tofu

(A theoretical framework developed from the research of Lestari et al. 2017)

\section{RESEARCH METHOD}

\subsection{Population and Sample}

The study was conducted at the production and sales centerof yellow Tofu on Jalan Pattimuran and Jalan Yos Sudarso, Kediri City, where the respondents were buyers of Yellow Tofu. The number of respondents in this study was 100 respondents, which refers to the opinion [11] that the minimum number of respondents is adequate in consumer behavior research. The sampling technique used is PurposiveSampling, which is a sampling technique that has specific considerations and criteria in selecting respondents. The criteria used in this study are as follows: 1) The age of the respondent is at least 21 years, 2) Has ever consumed yellow Tofu in Kediri, 3) Minimum education in high school / equal,4) has earned income.

\subsection{Data collection}

Data collection techniques used by interviews and questionnaires. The questionnaire in this study consisted of three parts, and the first part was a description or brief profile of respondents, the second part was about the attitudes of consumers towards the importance of the attributes of the Yellow Tofu product, the third part was about the level of consumer confidence in the characteristics of the Yellow Tofu product. The scale used is a Likert scale of 1 to 5. The indicators used are 1. Taste, 2. Nutrition, 3. Product Safety, 4. Texture, 5. Price, 6. Packaging, 7. Smell of tofu

$$
\mathrm{Ao}=\sum_{I=1}^{n} \text { bi.ei. }
$$

Ao: Attitude Towards Objects (yellow Tofu)

bi: Level/strength of the respondent's belief thatthe object has the attribute $\mathrm{i}$

ei: Respondent's evaluation of quality i N: Number of attributes on the object 


\section{RESULT}

\subsection{Profile of Respondents}

From the results of data collection and analysis, the following table explains the pattern of respondents in this study:

Table 1 Profile of Respondents

\begin{tabular}{|cc|l|l|}
\hline \multicolumn{2}{|c|}{ Profil respondent } & Total & Percentage \\
\hline 1. & Gender & & \\
a. & Male & 46 & $46 \%$ \\
b. & Female & 54 & $54 \%$ \\
\hline 2. & Education & & \\
a. & Higher & 37 & $37 \%$ \\
School & & 51 & $51 \%$ \\
b. & Bachelor & 12 & $12 \%$ \\
c. & Master & & \\
\hline 3. & Age & & \\
a. & $17-25$ & 46 & $46 \%$ \\
b. & $26-35$ & 6 & $6 \%$ \\
c. & $36-45$ & 36 & $36 \%$ \\
d. & $>46$ & 12 & $12,12 \%$ \\
\hline
\end{tabular}

Source: Primary data processed, 2020

From the results of data processing, based on gender characteristics, $54 \%$ of respondents were women. In comparison, in terms of education, the majority of respondents were high school educated at $37 \%$ of the total. While in terms of age, the majority of respondents aged 20 to 25 years, with a percentage of $46 \%$ of the total respondents.

\subsection{Consumer Attitudes Towards Attributes Interests}

Consumers will evaluate what attributes are considered necessary before making a purchase (Widiyanto et al.,2016). The average results of consumer attitudes towards the importance of the yellow tofu attribute are summarized inthe following table:

Table 2. Results of Mean Importance of Yellow Tofu Attribute (ei)

\begin{tabular}{|c|l|l|l|}
\hline No & Atribut & $\begin{array}{l}\text { Evaluation of } \\
\text { Importance }\end{array}$ & $\begin{array}{c}\text { Category of } \\
\text { importance }\end{array}$ \\
\hline 1 & Taste & 4.55 & $\begin{array}{l}\text { Very } \\
\text { important }\end{array}$ \\
\hline 2 & Nutrition & 4.48 & $\begin{array}{l}\text { Very } \\
\text { important }\end{array}$ \\
\hline 3 & $\begin{array}{l}\text { Safety } \\
\text { Product }\end{array}$ & 4.85 & $\begin{array}{l}\text { Very } \\
\text { important }\end{array}$ \\
\hline 4 & Texture & 4.30 & $\begin{array}{l}\text { Very } \\
\text { important }\end{array}$ \\
\hline 5 & Price & 4.15 & Important \\
\hline 6 & Packaging & 4.21 & $\begin{array}{l}\text { Very } \\
\text { important }\end{array}$ \\
\hline 7 & $\begin{array}{l}\text { Smell of } \\
\text { Tofu }\end{array}$ & 4.12 & Important \\
\hline
\end{tabular}

Source: Primary data processed, 2020
Based on Table 2, it is known that of the seven attributes of yellow Tofu, five characteristics are considered very important, namely the attributes of taste, nutrition, product safety, texture, and product packaging. Which of the five traits, product safety has the highest score of 4.85 , which shows that in buying yellow tofu Kediri, consumers prioritize product safety attributes before deciding to make a purchase. This correlates with the many issues of the use of hazardous substances in food processing, such as borax and formalin.

\subsection{Results of Mean Evaluation of Trust Strength of YellowTofu Attributes}

The assessment of consumer attitudes also uses the level of trust in attributes, from the results of evaluating the strength of the level of consumer confidence in Tahu Kuning Kediri,it can be seen in the following table:

Table 3. Average Results of Evaluation of Strength Trust (bi)Yellow Tofu

\begin{tabular}{|c|l|c|c|}
\hline N & Atribut & $\begin{array}{c}\text { Evaluate } \\
\text { the level of } \\
\text { trustin the } \\
\text { product }\end{array}$ & $\begin{array}{c}\text { Kategori } \\
\text { Tingkat } \\
\text { kepercayaan }\end{array}$ \\
\hline 1 & Taste & 4.36 & $\begin{array}{l}\text { Strongly } \\
\text { believes }\end{array}$ \\
\hline 2 & Nutrition & 4.21 & $\begin{array}{l}\text { Strongly } \\
\text { believes }\end{array}$ \\
\hline 3 & $\begin{array}{l}\text { Safety } \\
\text { Product }\end{array}$ & 4.06 & Believe \\
\hline 4 & Texture & 4.21 & $\begin{array}{l}\text { Strongly } \\
\text { believes }\end{array}$ \\
\hline 5 & Price & 3.39 & Believe \\
\hline 6 & Packaging & 3.61 & Believe \\
\hline 7 & $\begin{array}{l}\text { Smell of } \\
\text { Tofu }\end{array}$ & 3.82 & Believe \\
\hline
\end{tabular}

Source: Primary data processed, 2020

The results of data processing show that there are three attributes of Kediri yellow tofu that are trusted by consumers, namely taste, nutrition, and texture. This means that the three characteristics are following consumer expectations when buying and consuming products. Attributes of yellow Tofu Kediri get the highest level of trust, which is 4.36. This is consistent with Wood's theory, 2007, that taste is the most influential sensory aspect in product selection.

Nutrition attribute occupies the second position in consumer confidence in yellow Kediri tofu. Consumers generally believe that Yellow Kediri tofu has good nutritional content and is needed in the body because Tofu itself is a processed soybean that contains high protein. Texture Attributes gain the trust of consumers, the typical yellow tofu texture of Kediri City, which is not easily destroyed by consumers, because they can be 
combined into various types of dishes.

\subsection{Analysis of Consumer Attitudes Towards Kediri YellowTofu}

The attitude of consumers from the overall evaluation of the attributes of yellow Tofu Kediri is in the following table:

Table. 4. Results of Analysis of Consumer Attitudes Towards Yellow Tofu

\begin{tabular}{|c|c|c|c|c|}
\hline No & Atribut & $\begin{array}{l}\text { Importan } \\
\text { ce of } \\
\text { Attributes } \\
\quad \text { (ei) }\end{array}$ & (bi) & $\begin{array}{r}\text { Ao } \\
\text { (ei.bi) }\end{array}$ \\
\hline 1 & Taste & 4.55 & 4.36 & 19,838 \\
\hline 2 & Nutrition & 4.48 & 4.21 & 18,86 \\
\hline 3 & \begin{tabular}{|l} 
Safety \\
Product
\end{tabular} & 4.85 & 4.06 & 19.69 \\
\hline 4 & Texture & 4.30 & 4.21 & 18.10 \\
\hline 5 & Price & 4.15 & 3.39 & 14,06 \\
\hline 6 & Packaging & 4.21 & 3.61 & 15,19 \\
\hline 7 & $\begin{array}{l}\text { Smell of } \\
\text { Tofu }\end{array}$ & 4.12 & 3.82 & 15,73 \\
\hline
\end{tabular}

Source: Primary data processed, 2020

From the results of attitude analysis, taste attributes get the highest positive value from consumers; this means consumers get satisfaction from the taste attributes that existin yellow Tofu. So the conclusion of the analysis above is that the taste attribute is the attribute that gives the highest contribution to the competitiveness in the Kediri yellow tofu product. In comparison, the packaging attribute has the lowest score, which is 14.06 , where the price attribute does not get satisfaction from consumers when making product purchases.

\section{CONCLUSION}

The conclusions of this study are as follows:

- The attributes of the taste, nutrition, product safety, texture, and product packaging attributes are considered in purchasing the yellow tofu product.

- The taste, nutrition, and texture attributes in the Kediri yellow tofu product are following the consumers' considerations and desires in the product purchase decision. Meanwhile, the safetyand aroma attributes have not fulfilled or not by thewishes of consumers.

- Taste attribute gives the highest contribution to thecompetitiveness of tofu products

\section{ACKNOWLEDGMENT}

Our thanks go to all those who support this activity so that research can be completed smoothly.

\section{REFERENCES}

[1] R. Purwaningsih And P. Kusuma Damar, "Analisis Faktor-Faktor Yang Mempengaruhi Kinerja Usaha Kecil Dan Menengah (Ukm) Dengan Metode Structural Equation Modeling (Studi Kasus Ukm Berbasis Industri Kreatif Kota Semarang)," E-Journal Undip, Vol. 1, No. 1, Pp. 7-12, 2015.

[2] Ilhamudin, S. Nururly, And Rusminah, "Sikap Konsumen Terhadap Tahu Abian Tubuh Sebagai Produk Unggulan Sektor Makanan Kota Mataram," J. Magister Manaj. Unram, Vol. 8, No. 1, Pp. 35-45, 2019.

[3] N. Kusmariza, C. W. Vermila, And Maharani, "Analisis Prilaku Konsumen Terhadap Produk Tahu Di Desa Pasar Baru Pangean Kecamatan Pangean Kabupaten Kuantan Singingi Provinsi Riau," Agriture (Agribus. Futur., Vol. 1, No. 1, Pp. 48-57, 2013.

[4] D. Parestyna, "Analisis Sikap Konsumen Terhadap Produk Tahu Kuning Di Kota Kediri," Skripsi Univ. Sebel. Maret, 2013.

[5] P. Anggasari, L. N. Yuliati, And Retnaningsih, "Pengaruh Ethnosentrisme Terhadap Sikap, Preferensi Dan Perilaku Pembelian Buah Lokal Dan Impor," J. Manaj. Dan Agribisnis, Vol. 10, No. 2, Pp. 128-136, 2013.

[6] P. Kotler, Manajemen Pemasaran, Translation Of Marketing Management Analysis, Planning, Implementation, And Control., 7th Ed. New York: Prentice Hall International, 2000.

[7] O. Rahmawati, Dianah Umi; Antara, Made; Suryawardani, "Sikap Konsumen Terhadap Atribut Buah Jeruk Lokal Dan Impor Di Kota Denpasar," E-Jurnal Agribisnis DanAgrowisata, Vol. 7, No. 2, Pp. 222-231, 2018.

[8] M. H. Purwidiantoro, K. D. F. S.W, And W. Hadi, "Pengaruh Penggunaan Media Sosial Terhadap Pengembangan Usaha Kecil Menengah (Ukm)," J. Eka Cida, Vol. 1, No. 1, Pp. 30-39, 2016.

[9] Sudiyarto, "Sikap Kepercayaan Konsumen Sebagai Tolok Ukur Daya Saing Antara Buah Apel Lokal Dan Impor," Fak. Pertan. Upn "Veteran" Jawa Timur.

[10] S. P. M. Lestari, "Tolak Ukur Daya Saing Antara Buah Jeruk Lokal Dan Impor Dilihat Dari Sikap Konsumen Di Kota Semarang," Pp. 203-217, 2017.

[11] P. E. Green And V. Srinivasan, "Conjoint Analysis In Consumer Research: Issues And Outlook," J. Consum. Res., Vol. 5, No. September, 1978. 